\title{
Connecting the Dots between Social Care and Healthcare for the Sustainability Development of Older Adult in Asia: A Scoping Review
}

\author{
Khadijah Alavi ${ }^{1}$, Rosnah Sutan ${ }^{2, *}{ }^{\oplus}$, Suzana Shahar ${ }^{3}$, Mohd Rizal Abdul Manaf ${ }^{2}\left(\right.$, Mohd Hasni Jaafar ${ }^{2}\left({ }^{\circ}\right.$, \\ Khairul Nizam Abdul Maulud ${ }^{4,5}$ (D) Zaini Embong ${ }^{6}$, Kamarul Baraini Keliwon ${ }^{7}$ and Ruzian Markom ${ }^{8}$
}

Citation: Alavi, K.; Sutan, R.; Shahar,

S.; Manaf, M.R.A.; Jaafar, M.H.;

Abdul Maulud, K.N.; Embong, Z.;

Keliwon, K.B.; Markom, R.

Connecting the Dots between Social

Care and Healthcare for the

Sustainability Development of Older

Adult in Asia: A Scoping Review.

Sustainability 2022, 14, 2573. https://

doi.org/10.3390/su14052573

Academic Editors: Fei Sun and

Mihajlo (Michael) Jakovljevic

Received: 15 December 2021

Accepted: 9 February 2022

Published: 23 February 2022

Publisher's Note: MDPI stays neutral with regard to jurisdictional claims in published maps and institutional affiliations.

Copyright: (c) 2022 by the authors. Licensee MDPI, Basel, Switzerland. This article is an open access article distributed under the terms and conditions of the Creative Commons Attribution (CC BY) license (https:// creativecommons.org/licenses/by/ $4.0 /)$.
1 Centre for Psychology and Human Wellbeing, Faculty of Social Sciences and Humanities, Universiti Kebangsaan Malaysia, Bangi 43600, Selangor, Malaysia; khadijah@ukm.edu.my

2 Department of Community Health, Medical Faculty, Universiti Kebangsaan Malaysia, Kuala Lumpur 56000, Selangor, Malaysia; mrizal@ppukm.ukm.edu.my (M.R.A.M.); drmhasni@ukm.edu.my (M.H.J.)

3 Center for Healthy Aging and Wellness, Faculty of Health Sciences, Universiti Kebangsaan Malaysia, Kuala Lumpur 50300, Selangor, Malaysia; suzana.shahar@ukm.edu.my

4 Department of Civil Engineering, Faculty of Engineering and Built Environment, Universiti Kebangsaan Malaysia, Bangi 43600, Selangor, Malaysia; knam@ukm.edu.my

5 Earth Observation Centre, Institute of Climate Change, Universiti Kebangsaan Malaysia, Bangi 43600, Selangor, Malaysia

6 Centre for Governance Resilience and Accountability Studies, Faculty of Economics and Management, Universiti Kebangsaan Malaysia, Bangi 43600, Selangor, Malaysia; zainiembong@ukm.edu.my

7 Centre of Global Business and Digital Economy Studies, Faculty of Economics and Management, Universiti Kebangsaan Malaysia, Bangi 43600, Selangor, Malaysia; baraini@ukm.edu.my

8 Centre for International Law and Siyar (CILAS), Faculty of Law, Universiti Kebangsaan Malaysia, Bangi 43600, Selangor, Malaysia; ruzian@ukm.edu.my

* Correspondence: rosnah_sutan@yahoo.com or rosnah.sutan@ukm.edu.my; Tel.: +60-19-321-2256

\begin{abstract}
Globally, we face a rapid double growth of the ageing population that urges an integrated framework plan by connecting the health and social care disciplines as a shared and continuum of care approach. Bridging the gap between health and social care is required to meet the demand of ageing population needs, the readiness of the stakeholders, and community as a holistic approach. This article provides an overview of the evidence gap between social care and healthcare through a scoping review. Articles retrieved related to social and health care for older adults in the Asia region were identified through a compilation of PubMed, SAGE, Springer, and Google Scholar searches between the years 2015 to 2021 . Only twelve articles were used for result generation. The majority highlights the constraint on financial support, issues related to culture, human resource competency and community participation. The systematic review of the current work provides valuable insight for future researchers and policymakers in designing sustainable development integrated long term care (LTC) framework models and plans.
\end{abstract}

Keywords: sustainable development goals (SDGs); social care; health care; local communities; integrated care; elderly

\section{Introduction}

The ageing population phenomenon in most regions of Asia has increased drastically. It goes much faster than most developed European countries and the United States, which took more than 150 years to become an aged nation. However, recent literature identified that world ageing populations have shifted to East Asia and Southeastern Asia. The population aged 65 years or over almost doubled from $6 \%$ in 1990 to $11 \%$ in 2019 [1]. Singapore and Thailand's population above 65 years old was forecasted to reach more than $29 \%$ and $26 \%$ by 2040 [2]. This was followed by Vietnam (16.3\%); Brunei (16\%); Malaysia 
(12.9\%) and Indonesia (12.6\%). The life expectancy between Malaysia (76.3 years), Brunei (76 years) and Indonesia (71.7 years) with almost similar rates.

The increasing number of older persons is substantial for the dependency ratio. Meanwhile, Singapore shows the highest life expectancy of the elderly at 86 years, and Thailand is 77 years in the Asia region [2]. The dependency ratio of the elderly in Malaysia and Indonesia is almost the same, between 9-10 older people [3]. The calculation of this dependency ratio has not yet reached the classification as an old country [2,4]. However, Singapore and Thailand can be classified as ageing countries because the dependency ratio has reached 18 older adults aged 65 and above per 100 in terms of productive age population (15-64 years) [3,4]. A similar phenomenon will be experienced in Brunei, the Philippines, Myanmar and Cambodia. This phenomenon can also increase the demand for aged care services and the level of burden on family members' predominantly adult children, the community and the government. However, strategic planning on the integrated health and social care services and facilities needs to get underway in order to address the problems that may arise due to the acceleration in the elderly population in the future.

Many middle-income countries in Asia are predicted to be aged nations within a decade [3]. Considering this predicament, the government must prepare services and facilities to support the various needs of the elderly. Numerous health and social care services are available, but they operate without cohesion and collaboration. An integrated healthcare system has been shown as a good model for improving patient healthcare and reducing unnecessary healthcare resources [5]. However, sustaining a good project is always challenging, especially in countries with low financial allocation, multiethnic groups with various cultural beliefs, and political stability. Malaysia is one of the middle-income countries from the Southeast Asian region, which has multiracial with various religious beliefs and cultural practices. Currently, the aged group's Malaysian health care services focus on three main domains: physical health, psychosocial health, and nutritional/diet [6]. Not all aged people need to be taken care of by healthcare practitioners. Healthy and less disabled, aged people can be monitored in the community through good social healthcare with collaboration with healthcare services. There is pressure to initiate the collaborate of social and healthcare services facing the elderly with chronic diseases. The support services for dementia rehabilitation, psychotherapy, counselling, psychological treatment, and social work intervention is essential for the elderly to cope with personal and emotional assistance in the community setting [7].

Moreover, the Asian elderly preferred to live in a community rather than in institutional care. Family institutions provide care for the elderly in the community, especially in terms of shelter, safety, provisions, healthcare, financial, personal assistance, and emotional support. The social support and care industries are also essential factors in enhancing the wellbeing of the elderly compared to the formal care provided in hospitals, nursing homes and shelters [8]. Social care is an important sector integrated with the health care system, which fulfils effective and holistic services through practical social support innovations in enhancing the wellbeing of the elderly in the Asia region.

An integrated healthcare system should be ready to support the elderly population needs of the ageing country. A systematic review of the effectiveness of a multidisciplinary approach for chronic diseases post-hospital discharge has noted improved patient wellbeing and reduced unnecessary healthcare resources [5]. Suppose we want a similar concept as is seen in the multidisciplinary approach provided to the elderly population in the country with limited resources. How should it be focused, and how feasible is it? There is limited literature exploring coordinated care and the linkage between health and social care. Much of the literature highlights the need to bridge health and social care in meeting the primary demand of the elderly for future elderly care systems. The rapid increase in the elderly population in developed countries requires long-term plans with multidisciplinary and multi-agency integration using current technology [9]. However, the rapid increase of the elderly population in Asian regions or any developing countries may put more pressure on the existing health and social services that mainly focus on primary healthcare. Hence, 
integration between health and social services is required to minimize the cost burden and lack of skilled human resources among the elderly carer. Organizational changes and the involvement of relevant agencies to create a comprehensive and integrated system are essential for both health and social services [10].

Connecting health and social care is vital, as not all older adults have chronic diseases that need institutional care. Many of them are healthy and able to monitor themselves with minimal support. However, facilitating support is essential to integrated care between health and social. The rapid increase in the elderly population in developed countries requires long-term plans with multidisciplinary and multi agencies integration as it is overwhelmed with the cost for disease burden management. A study in the United Kingdom, a high-income country, reported that those countries planned care for people living with multimorbidity and long-term conditions started 20 years ago. They predicted the number of elderly will double by 2026 [8]. Community participation, issues on minority groups, and assessing homecare have been highlighted as essential but lacking integration. The rapid increase of the elderly population, especially within cities, put a burden on the existing health and social services. Hence, the need for integration between health and social services is at an all-time high, especially for those middle-income countries that will become aging countries in less than a decade. Telehealth has been implemented in many high-income countries under governmental and middle-income countries through private institutional services. A review of 25 health communities in England to introduce integrated health and social care for the elderly concluded that the requirement of organizational changes and the involvement of relevant agencies to create a comprehensive and integrated system is essential for both health and social services [9].

With the increase in the global population of older adults, health and social care integration has also undergone reforms to adapt to the supply and demand of elderly care and adjustment to the modernization-based family structure. The traditional role of elderly care by families as the informal caregivers and treatment models in hospitals or care institutions also transitioned towards being more client-focused and empowered the integration of health, social, and community aspects and technological consumerism [10].

The sustainability of health and social care is not just a family issue. However, the stakeholders must also address the community, private sector, non-governmental organizations, religious groups, and government. The proposed mitigation measures to ensure that the United States is prepared to address an increase in the ageing population include (1) investment for early development, (2) improving lifelong learning, (3) the engagement of older adults in society through employment incentives and volunteerism, (4) the empowerment of geriatric training to address the lack of human resources in elderly care, and (5) ensuring financial security through the redevelopment of social security and medical programs without increasing the cost to the government [11]. In most countries, long-term care policies and services are being developed in response to immediate political or financial constraints, not by building a sustainable system that integrates social care and health services. Even though there is an increase in research assessing the connection of health and social care of the elderly, there still exists space for improvement in preparing a framework that can map the relationship in a much more comprehensive manner. Few studies have been conducted in this area in the past $[1,12]$. Thus, the present review aims to bridge the gap between health and social care of the elderly in a strategic framework for the integrated long-term care (LTC) model tailored to the elderly's needs in the Asia region and to sustainable development with a focus on community-based implementation. For this reason, this article aims to collect relevant contemporary evidence and later will be used as a reference for future researchers or planners in planning for short, intermediate and long-term plans.

\section{Material and Methods}

The present review aims to identify the gap between healthcare and social care models implemented for the elderly in Asia by focusing on outcomes of interest. Our review 
assessed recent primary studies and reviews tailored to the evidence-informed policy formulation and implementation $[12,13]$. This review is written based on the systematic review writing guidelines and checklist [14-16]. As we included the review papers as well, it will allow us to get some information based on more than the past five years of studies that have been critically reviewed [16]. Recent studies in the Asian region highlighted three important aspects of connecting social and health care in planning for the long term population shift. Therefore, we conducted a literature review within the last five years that published evidence to explore issues, challenges in facing limitations, and technologies used in facilitating the bridging healthcare and social care for the population-base. Three outcome variables were studied: financial, human resources and the LTC model. The review protocol was designed, but we did not register in any systematic review registry. This review aims to provide an evidence-based synthesis for the national diagnostic study and long-term care plan for communities in Malaysia. The study's outcome will be used in Malaysian strategic planning for the elderly. When completing the review protocol we had already commenced data extraction.

\subsection{The Review Protocol}

The PRISMA Statement (Preferred Reporting Item for Systematic reviews and MetaAnalyses) $[14,16]$ is used as an outline to ensure (1) that the research is done comprehensively, (2) that the inclusion and exclusion criteria are stated clearly for reference, and (3) that quality assessment of scientific literature was undertaken in a defined time (Figure 1). The rigorous search based on medical subject headings (MeSH) was identified to assess the gap and successful connection between health and social care of the elderly using a proposed framework (Figure 2). The framework was created based on the literature review and experience of the authors. The findings obtained from the scoping review were mapped as a conceptual framework (Figure 2) and critically reflected the outcomes of interest [17]. Our review focuses on identifying knowledge gaps to help underpin evidence mapping and inform future research, and therefore is fit for a scoping review rather than systematic review according to the guidelines written by Munn et al. [18]. However, to provide evidence-based results for our national strategic planning for elderly care in Malaysia, we followed the systematic review methodology for literature assessment.

\subsection{Systematic Search Strategies}

The present review did not use any published clinical trial studies. Three research assistants (JCFY, FO, RR) were employed to do the literature search covering 2015 to April 2021 based on the criteria listed in Table 1. A search strategy was developed, and three researchers verified all retrieved related articles and stored them in the EndNote reference manager. We used removing duplicating function based on the same title, authors, journal and year of publication. PubMed, SAGE, Springer, and Google Scholar databases were chosen to identify publications using MeSH words listed in Table 2 based on the search string. We used all fields, set the time range from 2015 to 2021, and included human studies and observational studies. The studies selected were limited to the English and Malay languages with full-text access. All identified publications were screened for eligibility from the title and abstract. The researchers later reviewed and compared the studies findings according to the specified fields listed as outcomes (Table 1). For the Google Scholar advanced search, we browsed based on words that occurred in the title of the articles and with at least one word: older adult, elderly, geriatric and with all of the words: integrated, continuum, social and health care. We commenced searching for articles between January-April 2021. 


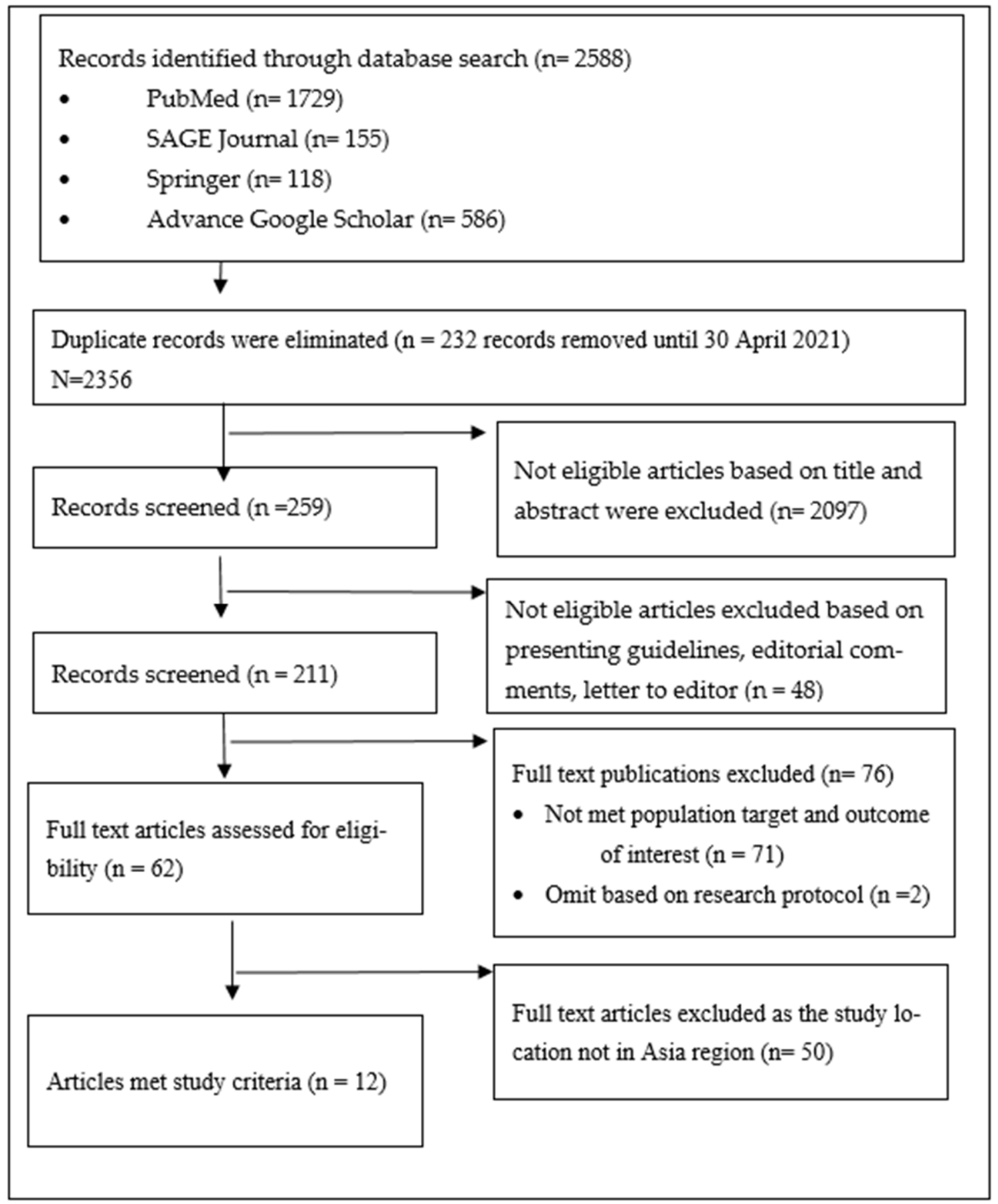

Figure 1. PRISMA study flow chart.

Table 1. Search descriptor for review.

\begin{tabular}{|c|c|}
\hline Criteria & Determinants \\
\hline Population & $\begin{array}{c}\text { Older adults ( } 50-59 \text { years old) and elderly (6o years and above) in Asia. } \\
\text { Elderly OR elderly persons OR older adults OR ageing OR senior citizens OR } \\
\text { old persons OR aged }\end{array}$ \\
\hline Intervention & $\begin{array}{c}\text { Received or provides social or health care for any form of needs for the elderly. } \\
\text { Formal or informal care, integrated care, continuum care, transitional care, } \\
\text { rehabilitation care, nursing, and mobilization care. }\end{array}$ \\
\hline $\begin{array}{l}\text { Comparator } \\
\text { outcomes }\end{array}$ & $\begin{array}{c}\text { None } \\
\text { Finance model, human resources, model of long-term care (LTC.) }\end{array}$ \\
\hline
\end{tabular}




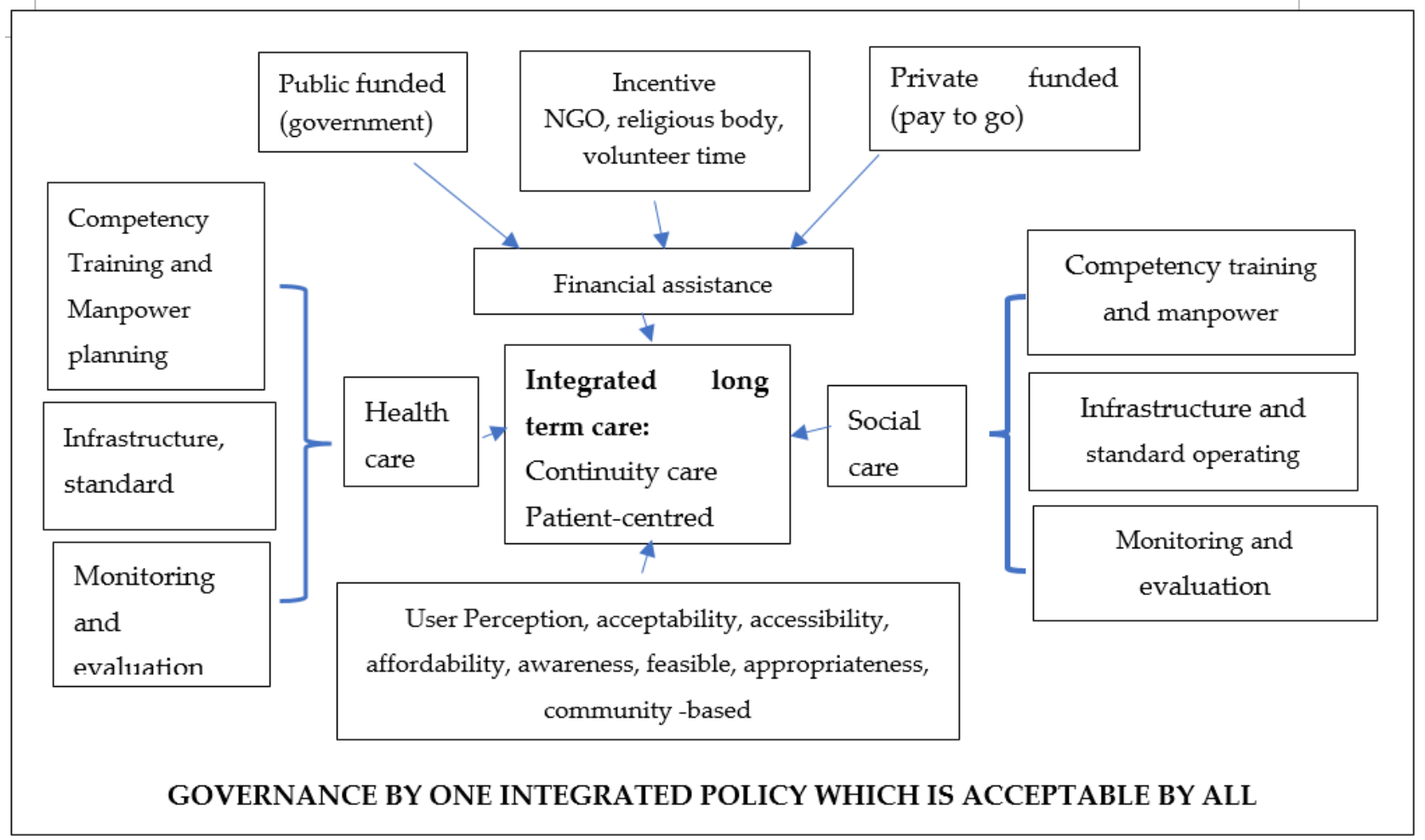

Figure 2. Framework model for long term care health and social integration.

Table 2. List of the search string.

\begin{tabular}{ll}
\hline Database & Search String \\
\hline \multirow{3}{*}{ PubMed } & Carers OR caregivers OR parental duties OR filial piety OR formal OR informal AND integrated \\
& care OR continuum care OR transitional care OR Asia. \\
& Filters applied:free full text, associated data, comparative study, meta analysis, review, systematic review, in \\
& the last 5 years, human, english, malay, MEDLINE, aged 60+ years \\
\hline & Needs OR gerontology OR geriatric OR welfare OR support OR nursing OR community service \\
& OR aid OR rehabilitation AND integrated care OR continuum care OR transitional care AND Asia \\
& Filters applied: [[Abstract needs] OR [Abstract gerontology] OR [Abstract geriatric] OR [Abstract \\
& welfare] OR [Abstract support] OR [Abstract nursing] OR [Abstract community]] AND [[Abstract \\
& service] OR [Abstract aid] OR [[Abstract rehabilitation] AND [Abstract integrated]]] AND [[Abstract \\
& care] OR [Abstract continuum]] AND [[Abstract care] OR [Abstract transitional]] AND [Abstract care] \\
& AND [Abstract asia] \\
\hline Sage Journal & Elderly OR older adults OR ageing OR senior AND social care AND health care AND integrated \\
care AND continuum care OR transitional care AND Asia AND Barrier AND long term care \\
Filters applied:Elderly OR older adults OR ageing OR senior AND social care AND health care AND \\
integrated care AND continuum care OR transitional care AND Asia AND Barrier AND long term care \\
\hline Social care service OR aged community-based OR elderly support service OR elderly social work \\
OR old age assistance OR elderly casework AND integrated care OR continuum care OR \\
transitional care \\
Filters applied:'Social care service OR aged community-based OR elderly support service OR elderly social \\
work OR old age assistance OR elderly casework AND integrated care OR continuum care OR \\
transitional care within English, Article
\end{tabular}

\subsection{Selection Criteria}

For this review, "elderly" is defined as people aged 60 and above. All published articles based on human study reports related to the elderly that discuss the health and social care perspective were included for this review. We added the word integrated as an exact phrase for advanced Google Scholar. We used additional filters like article type (comparative 
study, evaluation study) and language (English, Malay). In addition, studies conducted on non-human subjects, editorial comments, guidelines, and letters were excluded. All duplicated articles were removed from compilation files, including those articles that have been used in the review articles we selected. Ineligible articles based on a title and abstract which did not fulfil the criteria listed in Table 3 were excluded $(n=2097)$. Table 3 illustrates the indication criteria for the present review.

Table 3. Selection criteria for systematic review.

\begin{tabular}{cc}
\hline Item & Inclusion Criteria \\
\hline Date of a published article & 1 January 2015 to April 2021 \\
\hline Exposure of interest & $\begin{array}{c}\text { Social care model for elderly } \\
\text { Healthcare model for elderly }\end{array}$ \\
\hline The geographical location of the study & Asia \\
\hline language & Malay and English \\
\hline participants & Older adults (50-59 years old) and elderly (60 years and above) \\
\hline Reported outcomes of interest & Finance model, human resources, model of long-term care (LTC.) \\
\hline Study design & Systematic review, quantitative, qualitative and mixed-method study \\
\hline
\end{tabular}

\subsection{Selection of Articles}

The records from the database search were assessed for eligibility based on the title and abstract before retrieving the full text. Potential and eligible records were retrieved for full text and further screening on their suitability based on the criteria assessment (Table 3) conducted by two research assistants (FO and RR). Figure 1 outlines the process of selection. Two research assistants (JCYF and RR) retrieved full-text articles by downloading them from the website or requesting the help of our university librarian helpdesk assistant to retrieve them from national libraries and other various sources available. One research assistant and two authors (JCYF, KA and RS) reviewed the compilation of full-text articles. We omitted articles that did not mention any outcomes of interest, such as finance model, human resources, and model of long-term care (LTC). We critically appraised and assessed the risk of bias for each article. Two authors (KA and RS) finalized the assessment and created the evidence table with help from two research assistants (JCFY and RR). The third author (SS) was consulted for clarification. Selection criteria based on PICO (Tables 1 and 3) allowed us to choose related articles within the stated time and to conduct them systematically. There were four databases used in the present study. The PubMed database supports the search and retrieval of medical life science-related literature and is a favourable platform for publication by medical and health scientists. SAGE and Springer databases covered tremendous open access, focusing on humanities and social sciences studies. Google Scholar (advance search strategy) covers peer-reviewed and non- indexed publications.

\subsection{Risk of Bias}

The Mixed Method Appraisal Tool (MMAT) version 2018 [15] and AMSTAR checklist [16] was used as a guide. The risk of bias of the studies was summarised in the last column in Table 4 (risk of bias). Generally, the individual reported moderate to good based on the screening checklist fulfilled. The checklist adequately approaches the research question and findings with coherence among the sources, data collection, and analysis. Each "yes" as in the checklist was rated as " + ". Articles with more " + " scores mean better reporting and have reduced biases and random errors. 
Table 4. Table of evidence summary of included studies

\begin{tabular}{|c|c|c|c|c|c|c|c|c|c|c|}
\hline \multirow{2}{*}{ Reference } & \multirow{2}{*}{ Country } & \multirow{2}{*}{$\begin{array}{c}\text { Region } \\
\text { (Study Location) }\end{array}$} & \multirow{2}{*}{ Objective } & \multirow{2}{*}{$\begin{array}{l}\text { Study } \\
\text { Design }\end{array}$} & \multirow{2}{*}{ Sample Population } & \multirow{2}{*}{ Elements } & \multicolumn{3}{|c|}{ Study Output } & \multirow{2}{*}{$\begin{array}{l}\text { Risk } \\
\text { of } \\
\text { Bias }\end{array}$} \\
\hline & & & & & & & Finance Model & Human Resources & Model of LTC. & \\
\hline Briggs et al., 2018 [19] & $\begin{array}{l}\text { Australia, Belgium, } \\
\text { Canada, Finland, France, } \\
\text { Germany, Hong Kong, } \\
\text { Netherlands, New } \\
\text { Zealand, Norway, } \\
\text { Scotland, Singapore, } \\
\text { Spain, South Africa, } \\
\text { Sweden, Swititerland, } \\
\text { Taiwan, UK, USA. }\end{array}$ & $\begin{array}{l}: \text { Africa } \\
\text { Asia \& Pacific } \\
: \text { Europe } \\
\text { North America }\end{array}$ & $\begin{array}{l}\text { - To conduct a } \\
\text { review of } \\
\text { reviews in } \\
\text { evaluating the } \\
\text { integrated care } \\
\text { interventions for } \\
\text { older people }\end{array}$ & $\begin{array}{c}\text { Review of reviews Period: } \\
2015-2017\end{array}$ & 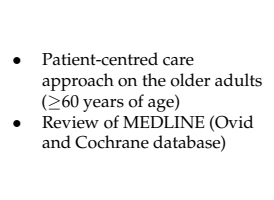 & $\begin{array}{l}\text { Mortality; hospitalization; } \\
\text { cost and resource } \\
\text { utilization; physical } \\
\text { functioning; } \\
\text { psychological functioning }\end{array}$ & $\begin{array}{l}\text { Various publicly and privately } \\
\text { funded models }\end{array}$ & $\begin{array}{l}\text { Nurses, physiotherapists, } \\
\text { general practitioners, and social } \\
\text { workers }\end{array}$ & $\begin{array}{l}\text { Community services } \\
\text { which may include the } \\
\text { non-government and } \\
\text { unpaid sectors }\end{array}$ & ${ }^{+++}$ \\
\hline $\begin{array}{l}\text { Chavez, Dwyer \& } \\
\text { Ramelet } 2018 \text { [20] }\end{array}$ & $\begin{array}{l}\text { Canada, Netherlands, } \\
\text { Taiwan, USA. }\end{array}$ & $\begin{array}{l}\text { : Asia \& Pacific } \\
\text { : Europe } \\
\text { North America }\end{array}$ & $\begin{array}{l}\text { - To identify and } \\
\text { summarise the } \\
\text { standard clinical } \\
\text { settings, } \\
\text { interventions, } \\
\text { and outcomes of } \\
\text { nurrese } \\
\text { practitioner care } \\
\text { specific to older } \\
\text { people }\end{array}$ & $\begin{array}{l}\text { Scoping review } \\
\text { Period: January } 1980 \text { and } \\
\text { March } 2016\end{array}$ & $\begin{array}{l}\text { - Masters-prepared nurse } \\
\text { practitioners providing care } \\
\text { for patients over } 65 \text { years of } \\
\text { age } \\
\text { CINAHL, EMBASE, } \\
\text { MEDLNE, Google Scholar, } \\
\text { Cochrane Collaboration and } \\
\text { Joanna Briggs } \\
\text { Institute databases }\end{array}$ & - Health & $\begin{array}{l}\text { - financial-related } \\
\text { outcome reported } \\
\text { benefits for home care } \\
\text { and long-term care } \\
\text { settings } \\
\text { - enhance key } \\
\text { financial-related } \\
\text { outcomes by } \\
\text { contributing to } \\
\text { decreased service } \\
\text { utilization and length } \\
\text { of stay }\end{array}$ & $\begin{array}{l}\text { - Nurse practitioners: } \\
\text { geriatric residency } \\
\text { programs unfilled } \\
\text { posts } \\
\text { - Emphasis on expert } \\
\text { knowledge and } \\
\text { competencies in } \\
\text { pathophysiology, } \\
\text { pharmacology, and } \\
\text { advanced } \\
\text { physical assessment }\end{array}$ & $\begin{array}{l}\text { Primary care, home care, } \\
\text { long-term care, acute care, } \\
\text { and transitional care }\end{array}$ & ${ }^{+++}$ \\
\hline Kirst et al., 2017 [21] & $\begin{array}{l}\text { Australia, Canada, France, } \\
\text { Italy, Netherlands, New } \\
\text { Zealand, Sweden, } \\
\text { U.S.A., UK, }\end{array}$ & $\begin{array}{l}\text { : Asia \& Pacific } \\
\text { Europe } \\
\text { North America }\end{array}$ & $\begin{array}{l}\text { - Toidentify } \\
\text { critical } \\
\text { processes that } \\
\text { lead to the } \\
\text { success or } \\
\text { failure of } \\
\text { integrated care } \\
\text { programs in } \\
\text { achieving } \\
\text { outcomes } \\
\text { reduced } \\
\text { healthcare } \\
\text { ualization, } \\
\text { improved } \\
\text { patient health, } \\
\text { and improved } \\
\text { patient and } \\
\text { caregiver } \\
\text { experience) }\end{array}$ & $\begin{array}{l}\text { Realist review } \\
\text { Period: January } 1980 \text { and } \\
\text { July } 2015\end{array}$ & 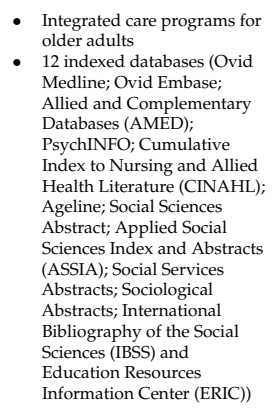 & : Health & 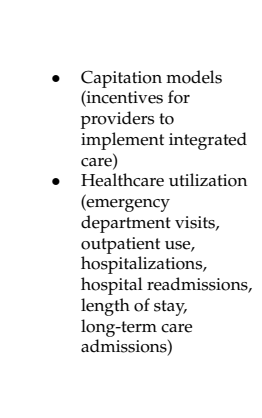 & $\begin{array}{l}\text { - Nurses, primary care } \\
\text { physicians, care } \\
\text { coordinators and } \\
\text { specialists. } \\
\text { - Strong leadership sets } \\
\text { clear goals and } \\
\text { establishes an } \\
\text { osganizational culture } \\
\text { supporting the } \\
\text { program } \\
\text { - trusting } \\
\text { multidisisiplinary } \\
\text { teams and } \\
\text { commintment to the } \\
\text { program model. }\end{array}$ & $\begin{array}{l}\text { - Community- } \\
\text { based } \\
\text { services } \\
\text { - joint governance } \\
\text { structures, } \\
\text { support team } \\
\text { collaboration } \\
\text { and } \\
\text { implementation } \\
\text { program } \\
\text { services (e.g.g. } \\
\text { social care } \\
\text { services, ,are } \\
\text { coordination } \\
\text { and planning) }\end{array}$ & ${ }^{+++}$ \\
\hline Stoop et al., 2019 [22] & $\begin{array}{l}\text { Canada, France, Germany, } \\
\text { Japan, Netherlands, New } \\
\text { Zealand, } \\
\text { Sweden, USA. }\end{array}$ & $\begin{array}{l}\text { : Asia \& Pacific } \\
\text { Europe } \\
\text { North America }\end{array}$ & 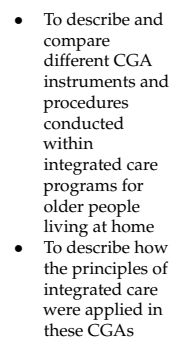 & $\begin{array}{l}\text { Scoping review } \\
\text { Period: 2006-2018. }\end{array}$ & $\begin{array}{l}\text { - Integrated care programs for } \\
\text { older people aged } 65 \text { years } \\
\text { and older living at home } \\
\text { - Medline PubMed, Embase } \\
\text { and Scopus }\end{array}$ & $: \begin{array}{l}\text { Health } \\
\text { Social }\end{array}$ & Not available & 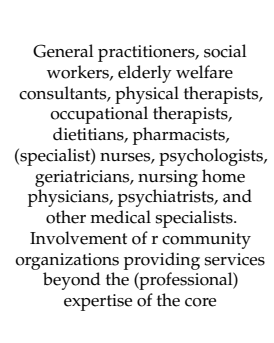 & $\begin{array}{l}\text { Home care needs to assess } \\
\text { frailty or } \\
\text { complex/multiple health } \\
\text { and social care needs in } \\
\text { various domains of life, } \\
\text { which may benefit frem } \\
\text { an integrated care } \\
\text { approach. The program } \\
\text { neeeds to enhance } \\
\text { professionals and } \\
\text { students's skills efficient } \\
\text { care, and quality of life. }\end{array}$ & ${ }^{+++}$ \\
\hline
\end{tabular}


Table 4. Cont.

\begin{tabular}{|c|c|c|c|c|c|c|c|c|c|c|}
\hline \multirow{2}{*}{ Reference } & \multirow{2}{*}{ Country } & \multirow{2}{*}{$\begin{array}{c}\text { Region } \\
\text { (Study Location) }\end{array}$} & \multirow{2}{*}{ Objective } & \multirow{2}{*}{$\begin{array}{l}\text { Study } \\
\text { Design }\end{array}$} & \multirow{2}{*}{ Sample Population } & \multirow{2}{*}{ Elements } & \multicolumn{3}{|c|}{ Study Output } & \multirow{2}{*}{$\begin{array}{c}\text { Risk } \\
\text { of } \\
\text { Bias }\end{array}$} \\
\hline & & & & & & & Finance Model & Human Resources & Model of LTC. & \\
\hline $\begin{array}{l}\text { Threapleton et al., } \\
\quad 2017[23]\end{array}$ & $\begin{array}{l}\text { Australia, Canada, } \\
\text { Hong Kong, } \\
\text { Italy, Netherlands, New } \\
\text { Zealand, Sweden, UK, } \\
\text { USA. }\end{array}$ & $\begin{array}{l}\text { Asia \& Pacific } \\
\text { Europe } \\
\text { North America }\end{array}$ & $\begin{array}{l}\text { - To inform health } \\
\text { system } \\
\text { improvements } \\
\text { by summarising } \\
\text { components of } \\
\text { integrated care } \\
\text { - in older } \\
\text { - populations } \\
\text { - To identify key } \\
\text { implementation } \\
\text { barriers and } \\
\text { facilitators }\end{array}$ & $\begin{array}{l}\text { Scoping review } \\
\text { Period: } 2005 \text { to February } \\
2017\end{array}$ & $\begin{array}{l}\text { - Integrated care approaches in } \\
\text { older/frail populations } \\
\text { MEDLINE, the Cochrane } \\
\text { LibDrary, roranizational } \\
\text { websites and internet } \\
\text { searches }\end{array}$ & : Health & $\begin{array}{l}\text { Funding should be realigned, } \\
\text { pooled, and ring-fenced to } \\
\text { facilitatet the integration of } \\
\text { services. }\end{array}$ & $\begin{array}{l}\text { Case managers, nurses, or social } \\
\text { workers }\end{array}$ & 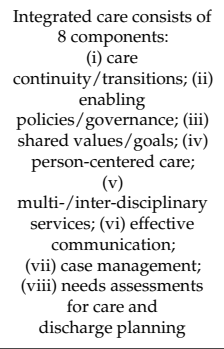 & ${ }^{+++}$ \\
\hline $\begin{array}{l}\text { Song, P.\& Tang, W. } \\
\text { 2019 [24]] }\end{array}$ & Japan & - Asia \& Pacific & $\begin{array}{l}- \text { To develop } \\
\text { personnel to } \\
\text { facilitate this } \\
\text { paradigm shift }\end{array}$ & Cross-sectional study & - Super-aged society & - Health & Not available & Nurse specialists & $\begin{array}{l}\text { Community-based (e.g., } \\
\text { providesa variety of } \\
\text { homes), } \\
\text { Institutional services (e.g.,. } \\
\text { strictly on physical and } \\
\text { mental status) }\end{array}$ & ${ }^{+++}$ \\
\hline $\begin{array}{l}\text { Du, P. \& Wang, Y. } \\
\text { 2016 [22]] }\end{array}$ & China & - China & $\begin{array}{l}\text { - To reconstruct } \\
\text { and consolidate } \\
\text { elder family } \\
\text { care capabilitities } \\
\text { and narrow the } \\
\text { gap amongst } \\
\text { various areses of } \\
\text { service provision }\end{array}$ & Policy review & $\begin{array}{l}\text { - Older persons ( } \geq 50 \text { years } \\
\text { of age } \\
\text { - Report and policy plan }\end{array}$ & $\begin{array}{l}\text { - Social and } \\
\text { healthare } \\
\text { integration }\end{array}$ & Not mentioned & $\begin{array}{l}\text { Emphasis on eldercare providers } \\
\text { within families as a foundation, } \\
\text { the conmunity as the base and } \\
\text { governmments/ agenencies as } \\
\text { supplementary }\end{array}$ & 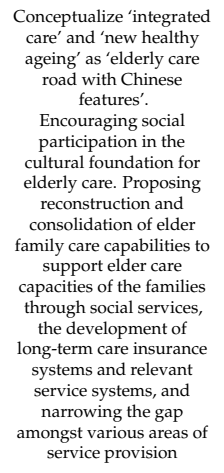 & ${ }^{++}$ \\
\hline $\begin{array}{l}\text { Cassum, Cash, Qidwai } \\
\& \text { Vertejee } 2020 \text { [26] }\end{array}$ & Pakistan & - Asia \& Pacific & $\begin{array}{l}\text { - To explore the } \\
\text { experiences of } \\
\text { the elderly } \\
\text { people } \\
\text { Po identify the } \\
\text { reason which } \\
\text { compelled the } \\
\text { elderly to reside } \\
\text { in theses shelter } \\
\text { homes }\end{array}$ & $\begin{array}{l}\text { Qualitative exploratory } \\
\text { study }\end{array}$ & $\begin{array}{l}\text { - } 14 \text { elderly males and females } \\
\text { purposively selected from } \\
\text { shelter homes }\end{array}$ & : Health & $\begin{array}{l}\text { The religious community } \\
\text { provide the funding based on an } \\
\text { assessment by SWB (Social } \\
\text { Welfare Board), lack of } \\
\text { family support }\end{array}$ & $\begin{array}{l}\text { Nurses, physiotherapists. } \\
\text { Capacity building training to } \\
\text { HCPs for the care of the elderly }\end{array}$ & $\begin{array}{l}\text { Shelter homes } \\
\text { need a policy on } \\
\text { retirement } \\
\text { Socio-cultural } \\
\text { value related. }\end{array}$ & ${ }^{+++}$ \\
\hline
\end{tabular}


Table 4. Cont.

\begin{tabular}{|c|c|c|c|c|c|c|c|c|c|c|}
\hline \multirow{2}{*}{ Reference } & \multirow{2}{*}{ Country } & \multirow{2}{*}{$\begin{array}{c}\text { Region } \\
\text { (Study Location) }\end{array}$} & \multirow{2}{*}{ Objective } & \multirow{2}{*}{$\begin{array}{l}\text { Study } \\
\text { Design }\end{array}$} & \multirow{2}{*}{ Sample Population } & \multirow{2}{*}{ Elements } & \multicolumn{3}{|c|}{ Study Output } & \multirow{2}{*}{$\begin{array}{c}\text { Risk } \\
\text { of } \\
\text { Bias }\end{array}$} \\
\hline & & & & & & & Finance Model & Human Resources & Model of LTC. & \\
\hline Sun et al, $2021[27]$ & $\begin{array}{l}\text { Canada, Hong Kong, } \\
\text { Philippines, Republic of } \\
\text { Slovenia, Sivitzerland, } \\
\text { UK, USA. }\end{array}$ & $\begin{array}{l}\text { : Asia \& Pacific } \\
\text { Europe } \\
\text { North America }\end{array}$ & $\begin{array}{l}\text { - To appraise the } \\
\text { adaptation of } \\
\text { older people's } \\
\text { transition to the } \\
\text { residential care } \\
\text { facilities }\end{array}$ & $\begin{array}{c}\text { Meta-synthesis } \\
\text { Period. from their } \\
\text { inception until April } 2020\end{array}$ & $\begin{array}{l}\text { Older adults } \\
\text { Six databaseses (CINAHL, } \\
\text { Cochranen, Embase, Pubmed, } \\
\text { Psycrnfo, and Web of Science) }\end{array}$ & - Health & Not mentioned & $\begin{array}{l}\text { Nurses caregivers involved in } \\
\text { the decision-making process }\end{array}$ & $\begin{array}{l}\text { Nursing care, } \\
\text { assisted living, residential } \\
\text { care, and long-term care, } \\
\text { transition } \\
\text { to residential care } \\
\text { facilities, cultural } \\
\text { adaptation }\end{array}$ & ${ }^{+++}$ \\
\hline $\begin{array}{l}\text { Lawless, Marshall, } \\
\text { Mittinty \& Harvey } \\
2020[22]\end{array}$ & $\begin{array}{l}\text { Australia, Canada, } \\
\text { Denmark, Netherlands, } \\
\text { New Zealand, Sweden, } \\
\text { UK, USA. }\end{array}$ & $\begin{array}{l}\text { : Asia \& Pacific } \\
\text { Europe } \\
\text { North America }\end{array}$ & $\begin{array}{l}\text { - To } \\
\text { systematically } \\
\text { map and } \\
\text { synthesize the } \\
\text { literature on } \\
\text { older adults' } \\
\text { perceptions and } \\
\text { experiences of } \\
\text { integrated care }\end{array}$ & $\begin{array}{l}\text { Scoping review } \\
\text { Period: June } 2008 \text { to July } \\
2019\end{array}$ & $\begin{array}{l}\text { Adults aged } \geq 60 \text { years } \\
\text { Electronic databases } \\
\text { (EMBASE, CINAHL, } \\
\text { PubMed and PArouest } \\
\text { Dissertation and Thesess) and } \\
\text { the grey literature (Open } \\
\text { Grey and Google Scholar) }\end{array}$ & - Health & Not mentioned & $\begin{array}{l}\text { Various healthcare settings, } \\
\text { including primary care, } \\
\text { hospitals, allied health practices } \\
\text { and emerrgency departments, } \\
\text { 'good' patient-provider } \\
\text { communication } \\
\text { and relationships, open } \\
\text { communucation and sharing } \\
\text { Decision-making, perceptions of } \\
\text { safety and care quality. }\end{array}$ & $\begin{array}{l}\text { Integrated (coordinated) } \\
\text { Healthare. Need to have } \\
\text { continuity, both in terms } \\
\text { of care relationshipss } \\
\text { and management, } \\
\text { seamless transititions } \\
\text { between care } \\
\text { services and /or settings, } \\
\text { and coordinated care that } \\
\text { delivers quick access, } \\
\text { effective treatment, } \\
\text { self-care } \\
\text { support, respect for } \\
\text { patient preferencese, and } \\
\text { involves } \\
\text { carers and families. }\end{array}$ & ${ }^{+++}$ \\
\hline Noda et al., 2021 [29] & $\begin{array}{l}\text { China, } \\
\text { Indonesia, Japan, } \\
\text { Phhilipines, } \\
\text { Thailand, } \\
\text { South Korea }\end{array}$ & • Asia \& Pacific & $\begin{array}{l}\text { - Th investigate } \\
\text { healthcare } \\
\text { reform policies } \\
\text { with a } \\
\text { framework } \\
\text { using tools } \\
\text { cross-oun for } \\
\text { comparisons }\end{array}$ & $\begin{array}{l}\text { Cross-country study } \\
\text { using documentreveview } \\
\text { and informat interview on } \\
\text { policy, strategy and } \\
\text { regulation on care } \\
\text { provision }\end{array}$ & - Elderly aged $\geq 65$ years & - Health & Not mentioned & $\begin{array}{l}\text { Strengthening Doctor and } \\
\text { hospital-based healthcare } \\
\text { delivery system, livelihood } \\
\text { support coordinator, }\end{array}$ & $\begin{array}{l}\text { Healthcare service } \\
\text { delivery policies, the } \\
\text { transformation of service } \\
\text { delivery system, long } \\
\text { term care and welfare. } \\
\text { National commission on } \\
\text { social security reform, } \\
\text { home care model, } \\
\text { community services } \\
\text { centre, integrated care, }\end{array}$ & ${ }^{+++}$ \\
\hline Wong et al., 2020 [30] & Hong Kong & - Asia \& Pacific & $\begin{array}{l}\text { - To study the } \\
\text { effectiveness of } \\
\text { a health-social } \\
\text { partresship } \\
\text { program for } \\
\text { discharged } \\
\text { non-frail } \\
\text { older adults }\end{array}$ & $\begin{array}{l}\text { single-blind randomized } \\
\text { controlled trial and follow } \\
\text { up observation. }\end{array}$ & - Patients aged 60 or over & : Health & $\begin{array}{l}\text { Departmental research fund of } \\
\text { the Hong King Polytechnic } \\
\text { University }\end{array}$ & $\begin{array}{l}\text { Advance practise nurse and } \\
\text { nurse case manager }\end{array}$ & $\begin{array}{l}\text { Health-social partnership } \\
\text { program }\end{array}$ & ++++ \\
\hline
\end{tabular}




\subsection{Analysis}

The articles were read systematically, and the key themes from the findings and discussion were extracted. Summary of findings from the literature was critically appraised and synthesized in specific themes based on the required outcomes. Results were then narratively examined. Coding of data was done systematically based on emerging themes. Compositions were synthesized and classified to form coding categories based on outcomes of interest. Data related to the selected report includes study location, objectives, study design, participants, outcomes of interest findings (financial model, human resource, LTC model) and level of risk of bias assessed. The economic model is defined based on the definition used in the published report [31] as (i) charge the elderly for service, (ii) formal personal care offer to the elderly free of charge through universal health care coverage through the government healthcare organization and (iii) universal elderly care insurance. Human resources are defined as qualifications, training, skills [32]. Model LTC is defined as long-term care programs that care providers designed based on long-term care service plans delivered by trained care managers [12,33]. Data were synthesized through narrative synthesis and MMAT guide for study limitation [15]. Findings of the present review were mapped and illustrated in the framework model for long term care health and social integration developed by the authors as a conceptual framework (Figure 2). We revisited UNFPA [1] and WHO [12] on the national plans on ageing to help us design the conceptual framework based on present reviews synthesis that focuses on long term care plans in integrating social and healthcare in the Asian region.

\section{Results}

\subsection{Review Selection}

About 2588 citations were found, with 2356 screened at the title and abstract stage after duplications or articles from similar resource surveys were removed. Two hundred and fifty-nine (259 articles) were deemed potentially significant, but after accounting for those editorial comments, poster presentation, proceedings, and letter to the editor, the number was reduced to 211. These studies underwent a full-text screening for inclusion, and 149 posts were ultimately deleted and another 50 eliminated for study location outside the Asia region, leaving only 12 articles [19-30] to be synthesized. The process can be seen in Figure 1 with the reasons for exclusion.

\subsection{Types of Reviews}

Table 4 displays the characteristics of twelve articles used for the review. The articles were published between the years 2015 and 2021. They consist of two systematic reviews 22 ,], four scoping reviews, one quick review literature search, one cross-sectional study, one qualitative study, one meta-synthesis, one cross-country study and one mixed-method study. Out of the twelve articles, seven were reviews containing primary studies from the Asia and Pacific region, following inclusion criteria for this review protocol. The remaining publications include a cross-sectional study (Japan), a qualitative study (Pakistan), a metasynthesis (China), a cross-country study of healthcare policies (China, Indonesia, Japan, Philippines, Thailand, and South Korea) and a mixed-method study (Hong Kong). The articles' sample population were older adults aged 50 years and above. One of the articles focused on care managers among the nurse practitioners who provide care for elderly patients. Out of the twelve articles, three discussed the elderly integrated care program. All articles contained social care and healthcare elements. One article [34] focused on the literature on interventions related to integrated care for older people by identifying critical elements for modelling.

\subsection{Focus of Reviews}

The researchers aimed to look at three components in the present review's study output: the finance model, human resources, and the model of long-term care (L.T.C.). Out 
of the twelve articles, seven did not specify or contain information regarding any finance model. For those that did include information about the financial aspect, one of them involved different types of models funded publicly and privately. Another publication used capitation models to encourage providers to carry out integrated care through incentives. The third article advised that funding needed to be reevaluated to achieve better service integration. Finally, the fourth article mentioned a financing system provided by the religious community.

Most $(n=10)$ reported more on medical specialists than people related to social care in human resources. The medical staff mentioned included general practitioners, nurses, physiotherapists, occupational therapists, dietitians and pharmacists. In comparison, only three publications mentioned social workers, case managers or psychologists. One other paper focused on providers of elderly care as being the family, government, and society.

For the third component, the model of long-term care (LTC), six articles looked into community-based services where they provide different types of homes to suit the needs of the elderly. Types of care were coded into acute care, primary care, home care, long-term care, and transitional care. Only one article suggested that community-based services include non-governmental agencies. In contrast, another study suggested the community as the base with family systems serving as the foundation and institutions relegated to supplementary support. The other three reports looked deeper into the characteristics and components of integrated care. These three reports also came out with eight elements that made up a successful integrated care approach focusing on person-centred care and shared values and goals. One report found determines the viability of a health-social partnership program in the pilot study and highlights its essential determinants. Another paper compared the healthcare service delivery policies placed in several Asian countries.

Reviews of articles related to intervention for integrated healthcare highlighted the lack of information, particularly on organizational and system service levels in the intervention project assessed based on the WHO ICOPE model approach [34].

\section{Discussion}

Most Asian cultures and nations rely on family and the community to care for their elderly $[3,10.14]$. Therefore, bridging the gap between health and social care is required to meet the demand of the ageing nation as a holistic approach. The present review identifies the gaps between existing social care and healthcare of older adults in Asian countries by focusing on three components: the finance model, human resources, and the model of long-term care (LTC). At each component, health and social care providers must outline in a matrix their plans with regard to specific activities: how it can be funded or paid out pocket and the planned implementation in the linkage system to provide shared and continuous care. The systematic review of the current work provides valuable insight for future researchers and policymakers in developing a sustainable integrated LTC framework model in practice.

Population ageing and the resulting epidemiological transition are problematic and would not be manageable by an acute-care, doctor-based system only. However, a growing ageing population experiencing delays in marriage, lower fertility rates, and an increase in living standards in most Asian countries mean that taking care of the elderly will become a crisis and negatively impact elderly wellbeing. In addition, extraordinarily high costs for people, households, and the country were noted. Therefore, integrating social care into the long-term care plan for the elderly is urgently required. Telehealth in connecting social care and health care requires good financial support in preparation for the system, equipment and promotion. Studies assessing the country plan on telehealth in improving the service delivery system reported challenges and barriers in its implementation, even among the high-income countries [9,17]. The gap between health care and social care needs to be minimized to provide a holistic approach toward the supervision of older adults. Emphasizing competent skills training [32,33] is essential in the LTC plan of action. They 
planned for human resource capacity and skill competency tailored to the local population's needs and culture.

Even a cursory glance at the publications included in this review shows that there is still much work to be done to provide long-term care to the older adult population in Asia. It is also essential to integrate social and health care to ensure that the needs and demands of the elderly and their caregiver are met comprehensively. However, achieving successful and sustainable integrated care is a long journey filled with trial and error. With one of the world's oldest populations, Japan started its insurance system covering universal social long-term care twenty years ago [33]. They are still reviewing and improving their long-term care system to suit the needs that have evolved over the years. Japan aims to establish integrated care at a community-based level before 2025 to assimilate more holistic care into medical care.

Limited studies were found in the Asia region related to long-term and integrated care for the elderly. Many literature reviews were conducted earlier [17-19] that assessed interventional care, but our study managed to identify specific gaps related to the financial model, human resource planning and method of LTC. With improvements in health care and socioeconomic status, people worldwide live longer. The life span age increases correlate with a country's increase in income status. However, not many studies are conducted to investigate how best to approach long-term care according to community need and the supported environment. This paper can surmise that care for the elderly is more focused on the medical aspect. Population ageing has challenges as many people survive to live longer, but not all would live well. Contracting with non-communicable diseases (NCDs) prevalent in diabetes, hypertension, obesity, and high cholesterol poses the most significant health threat to the elderly as a package of co-morbidities [19-21]. Social and psychological care takes a backseat as governments and healthcare staff focus more on improving the elderly's physical health [19]. The presence of a systematic review depicted a lack of counsellors, psychologists and social workers who participated in designing a long-term care plan. Long term care should be based on fulfilling needs respectfully, as shown in Figure 2. Figure 2 illustrates our findings from the present review. Health and social care will be determined by financial, shared continuum care services and qualified staff planning care and monitoring the results. The concept emphasised by WHO [35] was used as outlined in Figure 2 by the listed domains. The connectors act as process flow to bridge the gap between user and system provider at community-level implementation.

Figure 2 depicts the importance of every level of involvement through an empowerment program that includes individual, family and community participation. Issues on the structural organization should not be a barrier. Functionality is essential in determining the quality of life and longevity. Increasing chronic cases among older adults have been linked with dysfunctionality due to intrinsic body response capacity. However, a coordinated system without borders may promote user-friendliness and sustainability of any program intervention like integrated care or a community-based approach. A systematic review [19] on integrated care highlighted the importance of coordination of the clinical (micro), organizational/service (meso) or health system (macro) levels for the elderly. A good connection between social and healthcare will reduce the burden on managing chronic cases through shared care and improve individual functionality by inculcating preventive measures at the community level. A recent study done in Australia reported that similar needs and demands are required for integrated care which focused on (1) access to care, (2) the funding mechanism, (3) being tailored to the local community, and (4) the quality of care [36]. The planning in rural areas with limited resources needs to be cautiously assessed for sustainability [37]. Recent approaches highlight the possibility of using green care to help improve the psychosocial aspect of disease burden [38,39]. Green care is a concept that connects with nature, like contact with plants and animals. It is a model for improving social care, physical activity, mood, and creating entrepreneurship for financial support, and has been mentioned in a longitudinal study in Netherlands [40]. However, this model needs strong 
community participation and family involvement while the government of stakeholders supports providing infrastructure and training in enhancing sustainability [41,42].

\subsection{Strength and Limitation}

The strength of the present review is that it uses complete terms and reviewing reference lists of included studies to ensure completeness. We focused on Asia and hope it will guide us in identifying tailored information to local people. We review any articles published, as it will help us to review previous evidence, and we only focus on those periods not yet published in the review scope. One of the reviews articles [19] had reviewed previous studies on intervention for elderly care and integration care. Grey literature sources obtained primarily through Google Scholar were omitted in the result synthesis, but their opinion was used in the introduction part of this paper. We are from multidisciplinary backgrounds and should have different views, but we can agree with regard to our conceptual model developed from this review.

Limitations found in our search strategy may contribute to the missing of relevant papers not published online. Our approach regarding excluding non-older people may cut the caregiver involved as an essential aspect of human resources. The experience of caregivers would be a helpful addition to the literature.

\subsection{Implication and Sustainability}

Bridging health and social care is an essential attribute in making an excellent sustainable model of LTC for the elderly. The national plan for the elderly program needs to focus on the type of services, the financial support and the required human resource competencies. A recent study $[26,27]$ highlights the importance of financial security versus out of pocket money borne by the elderly for healthcare costs. However, future research should focus on these three attributes: finance model, human resources, and model of long-term care (LTC) in designing program interventions tailored to the local community.

The effective use of ICT technology in terms of recording, monitoring, and rating as a guideline facilitates coordination in the long-term care of the elderly (LTC). A sustainable LTC model for the elderly can be achieved by a comprehensive, integrated governance collaboration between the community, private sector, non-governmental organizations, religious groups, and government sectors. It has been suggested that regular social impact assessment research ensures the efficiency of service delivery by the government to the grassroots so that the community can optimize health and social care to achieve the happiness and wellbeing of healthy, positive, active and productive older persons. It is proposed that research and innovation be conducted periodically to adapt technology according to local cultural and religious modules.

The future research direction should focus on green governance theory. Each stakeholder entity will participate in green governance activities through negotiations and bind their respective comparative between social and health care advantages to achieve their respective goals. Hence, past studies have also shown that, theoretically, green climate psychology is a mediator influencing the relationship between green organizational governance and human capital behaviour. We suggest that future studies consider engaging in a multilevel approach to design a green economy and sustainable LTC model for older people in the Asia region.

\section{Conclusions}

This review highlights the need to bridge the gap between social and healthcare long-term care planning for the elderly in the Asia region, focusing on comprehensiveness, multidisciplinary, shared care, and continuum of care. The ultimate aim of having a practical model at the implementation level is to ensure sustainability and promote independent living in their homes and communities. Therefore, the care planning should focus on three main components: the financial model, human resources, and the long term care model. Involvement of all levels: individual, family, society, and stakeholders should be clearly 
outlined in the plan to make it sustainable. Connecting to nature is part of a model that needs to be assessed for implementation tailored to local acceptance. An ageing population has implications for nearly every facet of society, and each country needs to prepare for this demographic transition through a sustainable policy for long-term care. The rise in chronic disease and complex disabilities will make the elderly who live at home suffer from limitations that affect their quality of life. The proposed care must cover two-pronged health care and social care to support this situation. Asia and the Pacific region need to closely look into the social care aspects of their long-term care policies to ensure the best quality of life possible for our elderly population. The majority were severely affected by the population paradigm and belong to low to middle-income countries. Urbanization and demographic shifts will change socio-cultural values through adaptation needs and demands. However, due to multiethnicity, Asian populations with cultural diversity need to be considered. Cultural adaptation is a vital part of the assessment. The number of care providers with competent knowledge and good abilities in terms of the assessment and provision of comprehensive care based on the needs of the elderly has to be planned with an appropriate salary or allowance basis. Social care empowerment in community dwellers may foster collaboration and help to reduce the urge for hiring trained staff at minimal cost.

Author Contributions: All the authors have made a substantial contribution toward the successful completion of this manuscript. Conceptualization, K.A., S.S., R.S., M.R.A.M., M.H.J., K.N.A.M., Z.E., K.B.K. and R.M.; methodology, K.A., S.S. and R.S.; validation, K.A. and R.S.; formal analysis, R.S.; resources selection, K.A. and R.S.; writing-original draft preparation, K.A.; writing-review and editing, R.S.; funding acquisition, K.A. and S.S. All authors have read and agreed to the published version of the manuscript.

Funding: The authors gratefully acknowledge the APC and funding for this research work supported under UKM Pakarunding Sdn Bhd, grant number S190331.

Institutional Review Board Statement: The study was conducted according to the guidelines of the Declaration of Helsinki and approved by the Institutional Review Board (or Ethics Committee) of University Kebangsaan Malaysia Research Ethics Committee (S190331 and approved on 31 January 2021 with the title 'Diagnostic study to form a long-term care model for the elderly in Malaysia'.

Informed Consent Statement: This manuscript on a systematic review of the informed consent statement is not applicable.

Data Availability Statement: The study did not report any data.

Acknowledgments: The research ethic approval was obtained from University Kebangsaan Malaysia Research Ethics Committee with the financial assistance of the Universiti Kebangsaan Malaysia Pakarunding (S190331). This publication is acknowledged. The funder does not involve in the study's design, data collection, analytical, or manuscript preparation. The institutional review board approval was granted under University Kebangsaan Malaysia to conduct a follow-up survey based on present findings. Thanks to Joan Chen Yen Fong (J.C.Y.F.), Nur Fariza Omar (F.O.) and Mohd Redzuan Mohd Razali (R.R.) for their help in searching related papers and the critical appraisals.

Conflicts of Interest: The authors declare that they have no conflict of interest.

\section{References}

1. United Nations; Department of Economic and Social Affairs; Population Division. World Population Ageing 2019 (ST/ESA/SER.A/444); United Nations: New York, NY, USA, 2019.

2. Tiraphat, S.; Buntup, D.; Munisamy, M.; Nguyen, T.H.; Yuasa, M.; Aung, M.N.; Myint, A.H. Age-Friendly Environments in ASEAN Plus Three: Case Studies from Japan, Malaysia, Myanmar, Vietnam, and Thailand. Int. J. Environ. Res. Public Health 2020, 17, 4523. [CrossRef] [PubMed]

3. IndexMundi. 2021. Available online: https://www.indexmundi.com/factbook/compare/malaysia.indonesia.thailand. singapore/demographics (accessed on 31 January 2022).

4. Asian Development Bank. Country Diagnostic Study on Long Term Care in Thailand. 2020. Available online: https://www.adb org/sites/default/files/publication/661736/thailand-country-diagnostic-study-long-term-care.pdf (accessed on 21 March 2021). 
5. Damery, S.; Flanagan, S.; Combes, G. The effectiveness of interventions to achieve co-ordinated multidisciplinary care and reduce hospital use for people with chronic diseases: Study protocol for a systematic review of reviews. Syst. Rev. 2015, 4, 64. [CrossRef] [PubMed]

6. Ambigga, K.S.; Ramli, A.S.; Suthahar, A.; Tauhid, N.; Clearihan, L.; Browning, C. Bridging the gap in ageing: Translating policies into practice in Malaysian Primary Care. Asia Pac. Fam. Med. 2011, 10, 2. [CrossRef] [PubMed]

7. Scott, T.; Mackenzie, C.S.; Chipperfield, J.G.; Sareen, J. Mental health service use among Canadian older adults with anxiety disorders and clinically significant anxiety symptoms. J. Aging Ment. Health 2010, 14, 790-800. [CrossRef]

8. Balezdrova, N.; Choi, D.; Lam, B. 'Invisible Minorities': Exploring Improvement Strategies for Social Care Services aimed at Elderly Immigrants in the UK using Co-Design Methods. In Proceedings of the International Association of Societies of Design Research Conference, Manchester, UK, 2-5 September 2019; pp. 1-14.

9. Eason, K.; Waterson, P.; Davda, P. The sociotechnical challenge of integrating Telehealth and telecare into health and social care for the elderly. Int. J. Sociotechnol. Knowl. Dev. 2013, 5, 14-26. [CrossRef]

10. Lapre, F.; Stevenson, D.; Leser, M.; Horecky, I.J.; Kaserer, B.; Mattersberger, M. Long-Term Care 2030. European Ageing Network. 2019. Available online: https://www.ecreas.eu/uimg/ecreasportal/b80760_att-report-ean-ltc-2030-digital.pdf (accessed on 21 March 2021).

11. National Institute on Aging. "National Institute of Health. US Deparment of Health and Human Services". NIH. 2017. Available online: https:/ / www.nia.nih.gov/health/what-long-termcare (accessed on 8 January 2022).

12. World Health Organization. Framework on Integrated, People-Centred Health Services; World Health Organization: Geneva, Switzerland, 2016.

13. Strehlenert, H.; Richter-Sundberg, L.; Nyström, M.E.; Hasson, H. Evidence-informed policy formulation and implementation: A comparative case study of two national policies for improving health and social care in Sweden. Implement. Sci. 2015, 10, 169. [CrossRef]

14. Arksey, H.; O’Malley, L. Scoping studies: Towards a methodological framework. Int. J. Soc. Res. Methodol. 2005, 8, 19-32. [CrossRef]

15. Hong, Q.N.; Pluye, P.; Fàbregues, S.; Bartlett, G.; Boardman, F.; Cargo, M.; Dagenais, P.; Gagnon, M.P.; Griffiths, F.; Nicolau, B.; et al. Mixed Methods Appraisal Tool (MMAT), Version 2018, User Guide; Registration of Copyright (\#1148552); Canadian Intellectual Property Office, Industry Canada: Toronto, ON, Canada, 2018.

16. Shea, B.J.; Reeves, B.C.; Wells, G.; Thuku, M.; Hamel, C.; Moran, J.; Moher, D.; Tugwell, P.; Welch, V.; Kristjansson, E.; et al. AMSTAR 2: A critical appraisal tool for systematic reviews that include randomized or non-randomized studies of healthcare interventions, or both. BMJ 2017, 358, j4008. [CrossRef]

17. Malterud, K.; Bjelland, A.K.; Elvbakken, K.T. Systematic reviews for policy-making - critical reflections are needed. Health Res. Policy Syst. 2018, 16, 112. [CrossRef]

18. Munn, Z.; Peters, M.D.J.; Stern, C.; Tufanaru, C.; McArthur, A.; Aromataris, E. Systematic review or scoping review? Guidance for authors when choosing between a systematic or scoping review approach. BMC Med. Res. Methodol. 2018, 18, 143. [CrossRef]

19. Briggs, A.M.; Valentijn, P.P.; Thiyagarajan, J.A.; de Carvalho, I.A. Elements of integrated care approaches for older people: A review of reviews. BMJ Open 2018, 8, e021194. [CrossRef]

20. Chavez, K.S.; Dwyer, A.; Ramelet, A.-S. International practice settings, interventions and outcomes of nurse practitioners in geriatric care: A scoping review. Int. J. Nurs. Stud. 2018, 78, 61-75. [CrossRef] [PubMed]

21. Kirst, M.; Im, J.; Burns, T.; Baker, G.R.; Goldhar, J.; O'Campo, P.; Wojtak, A.; Wodchis, W.P. What works in implementation of integrated care programs for older adults with complex needs? A realist review. Int. J. Qual. Health Care 2017, $29,612-624$. [CrossRef] [PubMed]

22. Stoop, A.; Lette, M.; Van Gils, P.F.; Nijpels, G.; Baan, C.A.; de Bruin, S. Comprehensive geriatric assessments in integrated care programs for older people living at home: A scoping review. Health Soc. Care Community 2019, 27, e549-e566. [CrossRef] [PubMed]

23. Threapleton, D.E.; Chung, R.Y.; Wong, S.Y.-S.; Wong, E.; Chau, P.; Woo, J.; Chung, V.C.; Yeoh, E.-K. Integrated care for older populations and its implementation facilitators and barriers: A rapid scoping review. Int. J. Qual. Health Care 2017, 29, 327-334. [CrossRef]

24. Song, P.; Tang, W. The community-based integrated care system in Japan: Health care and nursing care challenges posed by super-aged society. Biosci. Trends 2019, 13, 279-281. [CrossRef]

25. Du, P.; Wang, Y.M. Population ageing and the development of social care service systems for older persons in China. Int. J. Ageing Dev. Ctries. 2016, 1, 40-52.

26. Cassum, L.A.; Cash, K.; Qidwai, W.; Vertejee, S. Exploring the experiences of the older adults who are brought to live in shelter homes in Karachi, Pakistan: A qualitative study. BMC Geriatr. 2020, 20, 8-12. [CrossRef]

27. Sun, C.; Ding, Y.; Cui, Y.; Zhu, S.; Li, X.; Chen, S.; Zhou, R.; Yu, Y. The adaptation of older adults' transition to residential care facilities and cultural factors: A meta-synthesis. BMC Geriatr. 2021, 21, 64. [CrossRef]

28. Lawless, M.T.; Marshall, A.; Mittinty, M.M.; Harvey, G. What does integrated care mean from an older person's perspective? A scoping review. BMJ Open 2020, 10, e035157. [CrossRef] 
29. Noda, S.; Hernandez, P.M.R.; Sudo, K.; Takahashi, K.; Woo, N.E.; Chen, H.; Inaoka, K.; Tateishi, E.; Affarah, W.S.; Kadriyan, H.; et al. Service Delivery Reforms for Asian Ageing Societies: A Cross-Country Study Between Japan, South Korea, China, Thailand, Indonesia, and the Philippines; Ubiquity Press, Ltd.: London, UK, 2021; p. 1.

30. Wong, A.K.C.; Wong, F.K.Y.; Ngai, J.S.C.; Hung, S.Y.K.; Li, W.C. Effectiveness of a Health-Social Partnership Program For Discharged Non-Frail Older Adults: A Pilot Study; BioMed Central Ltd.: London, UK, 2020.

31. Ohinata, A.; Picchio, M. The Financial Support for Long-Term Elderly Care and Household Saving Behaviour; GLO Discussion Paper, No. 43; Global Labor Organisation (GLO): Maastricht, The Netherlands, 2017.

32. Gospel, H.; Nishikawa, M.; Goldmann, M. Varieties of Training, Qualifications and Skills in Long-Term Care: A German, Japanese and UK Comparison; SKOPE research paper, no. 104; ESRC Centre on Skills, Knowledge and Organizational Performance (SKOPE): Cardiff, UK, 2011.

33. Kato, S.; Tsuru, S.; Iizuka, Y. Models for Designing Long-Term Care Service Plans and Care Programs for Older People. Nurs. Res. Pract. 2013, 2013, 630239. [CrossRef] [PubMed]

34. Williamson, C. Policy Mapping on Ageing in Asia and the Pacific Analytical Report. HelpAge International East Asia/Pacific Regional Office, Thailand. 2015. Available online: https:/ /www.refworld.org/pdfid/55c9e6664.pdf (accessed on 21 March 2021).

35. Review of Initiatives on Long-Term Care for Older People in the Member States of the South-East Asia Region; World Health Organization, Regional Office for South-East Asia: New Delhi, India, 2019.

36. Gunn, K.M.; Luker, J.; Ramanathan, R.; Ross, X.S.; Hutchinson, A.; Huynh, E.; Olver, I. Choosing and Managing Aged Care Services from Afar: What Matters to Australian Long-Distance Care Givers. Int. J. Environ. Res. Public Health 2021, 18, 13000. [CrossRef] [PubMed]

37. Koris, R.; Nor, N.M.; Haron, S.A.; Hamid, T.A.; Aljunid, S.M.; Nur, A.M.; Ismail, N.W.; Shafie, A.A.; Yusuff, S.; Maimaiti, N. The Cost of Healthcare among Malaysian Community-Dwelling Elderly. J. Ėkon. Malays. 2019, 53, 89-103. [CrossRef]

38. Li, W.; Xu, J.; Zheng, M. Green Governance: New Perspective from Open Innovation. Sustainability 2018, 10, 3845. [CrossRef]

39. Dumont, J.; Shen, J.; Deng, X. Effects of Green HRM Practices on Employee Workplace Green Behavior: The Role of Psychological Green Climate and Employee Green Values. Hum. Resour. Manag. 2016, 56, 613-627. [CrossRef]

40. Saleem, M.; Qadeer, F.; Mahmood, F.; Ariza-Montes, A.; Han, H. Ethical Leadership and Employee Green Behavior: A Multilevel Moderated Mediation Analysis. Sustainability 2020, 12, 3314. [CrossRef]

41. Artz, B.; Davis, D.B. Green Care: A Review of the Benefits and Potential of Animal-Assisted Care Farming Globally and in Rural America. Animals 2017, 7, 31. [CrossRef] [PubMed]

42. de Boer, B.; Hamers, J.P.; Zwakhalen, S.M.; Tan, F.E.; Beerens, H.C.; Verbeek, H. Green Care Farms as Innovative Nursing Homes, Promoting Activities and Social Interaction for People With Dementia. J. Am. Med. Dir. Assoc. 2017, 18, 40-46. [CrossRef] 